\title{
Poética, medicina e inquisição: o diálogo da perseguição nos Colóquios dos Simples e Drogas das Índias (1563) de Garcia da Orta
}

\author{
Poetics, medicine and inquisition: persecution \\ dialogue in Colóquios dos Simples e Drogas da \\ Índia (1563) by Garcia da Orta
}

\author{
Daniel Veccho Alves* \\ GeRsOn LUIZ Roani*
}

Resumo: Abordaremos, no presente artigo, que os aspectos relativos à medicina oriental se revelam como parte constituinte e não matéria única dos Colóquios dos Simples e Drogas da Índia de Garcia da Orta, médico particular do navegador Martim Afonso de Sousa. Na disposição dialógica por ele apresentada no citado texto, notaremos como os aspectos de sua identidade judaica trazem, à narrativa, tensões que visam driblar a censura inquisitorial, registrando as marcas poéticas suscitadas pelos vários conflitos político-religiosos travados com os católicos durante o Renascimento. Desse modo, fica nossa investigação longe de limitar-se à análise do registro dos fármacos Orientais até então desconhecidos no Ocidente, pois levaremos em consideração que, nos Colóquios, os diálogos ganham também um outro sentido ao se centrarem na marca dessa diáspora provocada pelos crimes e discriminações sociais de que os judeus e cristãos-novos ibéricos eram vítimas há tempos. Isso nos incentivará, por fim, a tomar os diálogos de Garcia da Orta como parte de uma larga literatura renascentista que se revela promissora para o estudo do campo estético em contextos de intensa censura, bem como para o estudo sobre o gradual surgimento de uma estrutura narrativa que prenuncia o romance burguês.

Palavras-Chave: medicina, inquisição, dialogismo, opressão

Abstract: The aspects related to Oriental medicine are revealed only as a constituent part of the Coloquios dos Simples e Drogas da Índia, wrote by Garcia da Orta. The dialogical layout his text reveal how catachreses and oxymoron bring to the narrative strategies

\footnotetext{
* Doutorando em História Cultural pela Universidade Estadual de Campinas.

** Professor Adjunto IV de Literatura Portuguesa da Universidade Federal de Viçosa (UFV), Minas Gerais.
} 
to head off the inquisitorial censorship, recording poetic marks raised by the various political and religious conflicts between Catholics and Jews during the Renaissance. This comparison will make our research be far from the limited view that classified this book as a simple registration of the Eastern unknown drugs, because our study will take into account that such dialogues earns another direction, focusing specially on the mark of this Diaspora caused by the mentioned conflicts and social discrimination that Jews and New Christians were victims since centuries ago. Its review will be very important for understand the Coloquios as a dialogic narrative resulted of this religion persecution, which takes accord to many intellectual works reflection that see this dialogues as a promising field for the study of the aesthetic in intense censor contexts, as well as for the study of the emergence of a narrative structure that pointing a presage of the bourgeois romance.

Keywords: medicine, inquisition, dialogism, oppression 


\section{Vejo erguer um grão Rei \\ Todo bem aventurado, \\ E será tão prosperado, \\ Que defenderá a grei.}

Este guardará a Lei

De todas as herzias,

Derrubará as fantezias,

Dos que guardão, o que não sei.

(Gonçalo Bandarra, Trovas)

\section{- As tribulações de Garcia da Orta pela Península Ibérica}

Em 1492, com a assinatura do Decreto de Alhambra promulgado pelos reis católicos da Espanha, ocorrera a expulsão dos judeus, inclusive daqueles que eram considerados intelectuais e cientistas, e prestavam serviço à corte. Além disso, quatro anos depois, para satisfazer uma exigência feita pelos reis Fernando e Isabel, o rei de Portugal, D. Manuel I, promulgou o édito de expulsão de judeus do território português, tal como os reis espanhóis haviam feito. Dava-se, assim, por terminada a expulsão e a conversão dos judeus da Península Ibérica.

A medicina dessa região muito perdera com tais expulsões, pois tratava-se de "uma das profissões cultas mais frequentemente exercida por judeus: na maior parte das cidades portuguesas do século XV, por exemplo, os médicos judeus eram mais numerosos que os médicos cristãos" (WILKE, 2009, p. 34). Para além de desempenharem a função de médicos, destacavam-se como astrônomos e matemáticos, participando ativamente nos progressos técnicos que levaram às descobertas marítimas ${ }^{1}$. Todavia, com a política religiosa opressiva dos séculos

\footnotetext{
1 "Entre os séculos XII e XIV destaca-se a família Ibn Yahya cujos membros foram eminentes médicos sendo um dos mais conhecidos Ibn Yahya ben Salomon ligado ao rei D. Fernando de Portugal. Para além desta família, destacaram Moisés Navarro, rabi-mor e médico de D. João I e D. Pedro I, mestre Abraão Guedelha, físico de D. Duarte e de D. Pedro II, mestre Tomás da Veiga e mestre Rodrigo da Veiga, médicos de D. Afonso V, e também José Vizinho, físico e conselheiro de D. João II" (FRADE; SILVA, 2011, p. 52-53).
} 
XV e XVI, culminando nessa expulsão e conversão forçada, temos uma época marcada por perseguições, condenações, confiscos e tributos, resultando tal política na emigração contínua de cientistas e intelectuais.

Tal perda foi considerável, tanto que "a dispersão dos médicos judeus impedira o aparecimento duma verdadeira nova escola médica, [...]" (FRADE; SILVA, 2011, p. 54). Os físicos desterrados acabaram por adquirir no estrangeiro uma boa reputação pelo alto nível técnico-científico que apresentavam. No entanto, sabemos que nessa época a prática da medicina estava ainda muito arraigada na magia, na alquimia e no ocultismo, sendo frequente na Europa a prescrição médica baseada em deduções astrológicas e místicas. Procurava-se resolver problemas de saúde pela consulta de magos e até mesmo rabinos, e os próprios médicos eram incentivados a estudar astrologia e outros conhecimentos que eram partilhados por escolares e camponeses².

Mesmo diante dessa forte presença popular na prática médica, separava-se o ensino universitário da aprendizagem prática e do que se descobria informalmente. Porém, a partir dos Descobrimentos, o conhecimento medicinal e sua prática se expandem consideravelmente. Há um renascimento nos saberes médicos ocidentais não só pelo regresso às fontes clássicas, mas, sobretudo, pela incorporação na medicina de novas drogas, especialmente aquelas descobertas no Oriente depois de 1498, novidades que, por sua vez, eram divulgadas pela nascente imprensa europeia.

Nesse ínterim, a prática médica foi sendo renovada entre os judeus a partir de uma perspectiva estética bíblico-filosófica e experimental que foi gradualmente se emancipando das autoridades místicas e clássicas:

A primeira geração de cristãos-novos era composta de grandes leitores, muito dados à versificação e impregnados de cultura estética e literária própria do barroco hispânico. Ao gosto da época, criaram adaptações poéticas de textos bíblicos, como a da narrativa da Criação, [...]. Os <<judeus-novos >> não eram apenas apreciadores de belos versos. Gostavam igualmente de textos polêmicos,

2 Paracelso (1493-1541), por exemplo, acreditava que a função de um médico ia além do diagnóstico e receituário convencional; era necessário um estudo do paciente e uma compreensão da doença em aspectos como a astrologia, alquimia, magia e outras variações esotéricas. 
que mostravam que o judaísmo era mais racional do que o cristianismo. (WILKE, 2009, p. 139-140)

Ademais, nos séculos XVI e XVII, salientou-se um novo tipo de escrita acerca do conhecimento medicinal que contemplava a ideia de que a medicina possui fins naturais e humanos, sobretudo, políticos. Essa característica aliada à mentalidade inquisitorial conduziu a produção de obras como os Colóquios de Garcia da Orta (1500?-1563), o Retrato del Perfecto Medico (1603) de Henrique Jorge Henriques (1545-1633) e o Medicus Politicus (1614) de Rodrigo de Castro (15411627). A "literatura médico-política" dessa época, como é chamada por David Ruderman, emerge de uma realidade marcadamente determinada pela Inquisição, na qual a medicina permitida pelo Santo Ofício normalizava e controlava disciplinarmente a conduta do corpo e do espírito:

O saber herbóreo europeu, a despeito de sua evolução no caminho de uma sistemática científica, foi, antes disso, [...], uma verdadeira descrição de [...] etnografia moral dos usos dos alucinógenos, dos afrodisíacos e de outros remédios, passando a sofrer um controle cada vez maior da onda repressiva que se abateu sobre o mundo no final do século XVI com a intolerância religiosa e a inquisição tornando os Estados cada vez mais fortes e absolutos. (CARNEIRO, 2002, p. 13-14)

Por conseguinte, os médicos judeus, mesmo cada vez mais pressionados pela Igreja, parecem se compromissar com o desenvolvimento de uma atitude escritural em defesa do proselitismo judaico entre os cristãos-novos, condensando a matriz espiritual, profética e messiânica de sua cultura no topos sebástico que marcará, por exemplo, a cultura portuguesa nos tempos subsequentes ${ }^{3}$. Além disso, em tais obras médicas, encontramos, geralmente, a utilização de um disfarce poético por meio do diálogo filosófico ou pastoril, com o intuito de relatar

\footnotetext{
3 É quase unanimidade entre os historiadores a importância cultural do judaísmo na formação do processo ultramarino português tanto em termos de técnica, quanto de imaginário. Acrescenta o historiador Jaime Cortesão, por exemplo, que os descobrimentos iniciados pelo Infante e prosseguidos por D. João II não podem ser compreendidos em toda a sua complexidade e eficácia "sem entrar em linha de conta com essa comunidade ibero-árabe de cultura, que tinha por supremos intérpretes os mercadores judeus" (CORTESÃO, 1960, p. 107).
} 
os costumes do povo judaico: tratava-se de uma estratégia para eliminar a distância cultural e histórica por meio de uma filiação poética de identidade.

Esses médicos, em Portugal e no estrangeiro, desenvolveram a botânica médica, a anatomia, a medicina legal, a história da medicina, etc. Cabe salientar que as obras que abrangiam essas áreas eram mais bem quistas pela corte e pelo clero, e tinham mais permissão e investimento para ir a prelo. Por isso, D. Manuel ao "proibir de adquirir ou manusear livros hebraicos, considerou como especial privilégio o fato de permitir aos médicos e cirurgiões convertidos - dos quais havia muitos no país - o emprego de obras médicas [...]" (KAYSERLING, 2009, p. 180).

Tal abertura possibilitou o surgimento de homens como Garcia da Orta, cuja profissão de médico e investigador da botânica não tirara o gosto de criar e filosofar sobre sua experiência humana e sua religião proibida. Nascido por volta de 1500, "Garcia da Orta era proveniente de uma família de judeus espanhóis dedicados ao comércio". Seu pai, Fernão da Orta, "converteu-se ao cristianismo em 1497" (BARRETO, 1983 p. 255), transferindo-se para Portugal na mesma década.

É mais que provável que sua família se mudou para as terras lusitanas pressionada pela expulsão dos judeus em vigor depois do édito dos Reis Católicos de 1492, que expulsava da Espanha todos os israelitas. Tal motivo foi suficiente para que seu pai passasse a exercer a sua atividade mercantil na zona de Castelo de Vide, onde, opinam alguns biógrafos, possivelmente nascera Garcia da Orta 4 .

Os acontecimentos que se sucederam com seus parentes após o ano de sua morte nos dão a convicção de que Orta provinha de família de judeus fugidos para Portugal na grande migração de 1492. Além do ambiente hostil que envolvera a época do seu nascimento, sua morte também não se deu de modo pacífico. Falecido em 1568, foi enterrado em solo sagrado da própria Sé de Goa para depois ser queimado em auto de fé. O motivo foi descoberto por Augusto da Silva Carvalho, que pesquisou, nos processos da Inquisição de Goa, sobre a condenação inquisitorial de Catarina de Orta, a irmã de Garcia que havia sido presa naquele ano e na mesma cidade indiana.

\footnotetext{
4 "[...] Fernão de Orta, natural de Valência de Alcântara, povoação situada a pouca distância de Marvão, que exercia o mister de mercador, veio de sua terra, onde residia, para Castelo de Vide e aqui continuou a exercer a sua profissão, tanto mais facilmente, quanto era certo, que pelo seu negócio e pela proximidade das duas terras conhecia e tratava já com muitos portugueses que encontrava nos mercados e feiras" (CARVALHO, 1934, p. 11).
} 
Aterrorizada como todos os prisioneiros do Santo Ofício, Catarina da Orta entregou muitas pessoas de sua estirpe à Inquisição, o que não impediu de a condenarem em auto de fé ocorrido no ano seguinte ao da sua prisão. No Códice 203 do Fundo Geral da Biblioteca Nacional de Lisboa, Carvalho encontrou, nos números 1282 e 1283 da Inquisição de Lisboa, duas cópias desse processo movido pelo recente tribunal instalado em Goa.

Nesse processo, Catarina confirma que sua mãe usava práticas da lei judaica e que em Lisboa a industriara. Denunciou também seu marido, "se referindo ainda às pregações de seu irmão que seguiu, mas havia cinco anos abandonara voltando a ser cristã" (CARVALHO, 1934, p. 74). Sobre o irmão, ainda "revelou que fora casado com uma senhora, descendente de família castelhana judaica e que dela tivera duas filhas" (LUZES, 2008, p. 90). Ou seja, ao ser acusada de heresia, no intuito de se defender, lançou também várias suspeitas sobre a religião de sua família. Tais acusações fizeram que o tribunal da inquisição decidisse, mais tarde, que os ossos de Garcia da Orta fossem arrancados da Sé de Goa para serem queimados. Esse triste acontecimento deu-se em dezembro de 1580.

No importante processo descoberto e estudado por Carvalho, confirma-se a identidade judaica de Garcia da Orta, o que nos incitará aqui investigar as marcas discursivas dessa identidade nos seus famosos Colóquios. No entanto, para isso é preciso partir do que se sabe mais seguramente de Garcia da Orta para melhor reconhecermos essa presença. É sobre sua passagem pelas academias na Espanha, onde estudou medicina nas Universidades de Salamanca e Alcalá de Henares, que temos mais testemunhos, como, por exemplo, o licenciado Dimas Bosque, que no prólogo publicado nos Colóquios nos diz ter Orta "saído ensinado nos princípios das insignes universidades de Salamanca e Alcalá" (ORTA, 1987, p.10).

No seu tempo, em Salamanca, ainda não havia surgido os estudos de botânica e de matéria médica, porque o mesmo aconteceria somente anos depois. Mas, em Alcalá, "Orta conhece Antonio de Nebrija (1441-1522), que o iniciou no ensino da botânica, que não foi só livresco, como Ficalho supôs, mas se efectivou também por excursões de herborização, o que muito deve ter agradado ao aluno português, estimulando-o para o conhecimento prático da natureza" (CARVALHO, 1934, p. 15).

Depois de terminar seus estudos, Orta vai para Lisboa em 1525, a fim de concorrer à cadeira de lógica e filosofia da natureza. Somente em 1531 é que con- 
segue ser eleito para essa cadeira nos Estudos Gerais de Lisboa5 ${ }^{5}$. Porém, poucos anos depois, algo inusitado ocorre para que ele deixe o cargo acadêmico pelo qual ele tanto lutara para conseguir. Semelhante à sua família que largara tudo na Espanha para tentar a vida nas fronteiras portuguesas, Garcia da Orta, em 1534, parte rumo ao desconhecido Oriente na esquadra do navegador Martim Afonso de Sousa.

\section{A importância das navegações para a sobrevivência e para o alargamento do conhecimento medicinal de Garcia da Orta}

Inicialmente, podemos nos perguntar o porquê Garcia da Orta opta por afrontar os inconvenientes e perigos mortais da carreira da Índia, sendo que havia igual possibilidade de fuga para a Holanda e para outros países muito mais próximos da Península Ibérica que acolhiam bem os cristão-novos como ele? Uma hipótese é a de que os judeus daquela época miravam o horizonte do mar com base nas vagas e imaginárias notícias sobre a existência de grupos judaicos sobreviventes na Índia e na Etiópia.

Por isso, cientistas e mercadores judeus como Garcia da Orta, de carreira e cultura itinerante, possuíam o mais vivo interesse no descobrimento do Oriente, porque para eles isso "significava uma surpreendente aproximação das regiões de sua geografia até então puramente imaginária, em que se situariam reinos independentes formados outrora por famílias exiladas da antiga terra de Israel e de Judá" (LIPINER, 1987, p. 17).

A esta "força expulsiva" juntavam-se outras atrativas como "o espírito de aventura, a ânsia de ver novas terras, tão acentuada nos israelitas e ainda mais a curiosidade científica de explorar o Oriente magnífico e misterioso, que fascinava nacionais e estrangeiros; [...]" (CARVALHO, 1934, p. 20). Outra possível causa que pôde justificar e autorizar sua viagem à Índia é a notável capacidade de Orta em enfrentar um dos males mais temíveis que se proliferava no Oriente: a cólera.

\footnotetext{
5 Para saber mais sobre a passagem de Orta pela academia de Lisboa ver o estudo do Dr. Teixeira de Carvalho intitulada Garcia d'Orta. Notas sobre sua passagem pelo Estudo e Escolas Gerais de Lisboa (1527-1534), Imprensa da Universidade de Coimbra, 1915.
} 
Sabe-se, entre os vários cronistas, da terrível epidemia dessa doença que vinha assolando a cidade de Goa. Como descreveu o médico, o flagelo dizimava a todos sem distinção:

Ruano: E vós os Portuguezes que lhe pondes, ou que Ihe fazeis? Orta: Damoslhe a comer perdizes e galinhas estiladas, ou çumo dellas: tambem lhe damos toradas de vinho com canella; postoque estas cousas quentes eu nam uso muyto nos comeres, senam postas pela parte de fora, untando o estamago com olio de almecega e nardino quentes; trabalho com muyta presa de limpar o estomago com mezinhas lavativas somente, e com cristeis; [...]. Todavia porque esse humor, que he venenoso, não enfecione o outro, he bem que se deite fóra cedo; [...]. (ORTA, 1987, p. 265)

Uma investigação consistente das causas dessa doença era de interesse do Governador para compreender e melhor dominar esse temível inimigo. Garcia de Orta optou certamente por participar dessas investigações. Em Colóquios dos Simples, o médico integrou no Coloquio décimo sétimo, do Costo e da Colérica passio, a primeira descrição sobre a etiologia dessa enfermidade que, uma vez contraída, podia matar em 24 horas: "Acerqua de nós he colerica passio; e os Indianos lhe chamão morxi; [...]. Cá he mais aguda que em nossas terras, porque comumente mata em vinte quatro oras; [...]" (ORTA, 1987, p. 261).

Revelando-se conhecedor dos sintomas e detentor dos segredos da cura, o médico demonstrou, com a sua obra, a importância médica da sua presença em Goa. No entanto, além do seu valor como físico, Conde de Ficalho defende a hipótese de que ele contava com uma forte proteção de Martim Afonso de Sousa, que muito era estimado na corte lusitana antes de realizar sua primeira viagem ao Oriente. Essa proteção parece ter sido vital para que Orta fosse levado em sua esquadra, pois se sabe que, naquele tempo, ainda não era comum a presença de físicos que acompanhavam os capitães do mar, concedendo-lhes o título de físico-mor: "As armadas não possuíam físicos em sua tripulação, só cirurgiões religiosos ou leigos, sangradores e barbeiros. Por isso, julgo que Orta teve certa distinção e privilégio ao ser permitido embarcar nessa esquadra" (CARVALHO, 1934, p. 21).

De qualquer forma, Garcia da Orta nunca mais retornará da Índia, escapando à proibição, editada em 14 de junho de 1534, de durante três anos saírem do 
reino os cristãos-novos. Orta foge sob o abrigo do seu possível protetor Martim Afonso, que preparava a sua ida para a Índia como capitão-mor do mar. Pelo amplo espaço dado às descrições dos lugares e dos homens, é possível também vermos os Colóquios como um relato da viagem de Martim Afonso de Souza pelo Oriente. Não é por menos que no prólogo da obra localizamos a dedicatória de Orta a seu capitão: “Ó que poderá, ilustríssimo senhor, tornarse Homero ou Virgílio pera escrever vossas grandes façanhas, pera com isto deixar fruto de mi aos vindoiros" (ORTA, 1987, p. 4).

Em contrapartida, no reino português, "a imagem do fidalgo tinha sofrido uma importante deterioração durante o seu governo no Oriente. A chegada apartada do seu navio a Lisboa, deixando para trás as outras naus da armada, atesta bem o desconforto que envolvia o seu nome" (CARVALHO, 2015, p. 80). Por isso, na dedicatória feita a esse navegador, Garcia da Orta parece ter desejado recuperar a sua nobre memória e salientar a admiração que os portugueses espalhados por toda a Ásia nutriam pela sua pessoa e pelo trabalho que, no Oriente, realizara.

Para tanto, Orta não deixou de relatar a sua experiência enquanto médico pessoal desse capitão durante as suas muitas incursões às cortes orientais ${ }^{6}$. Nem Vasco da Gama conhecera a Índia como Orta, pois por ordem do rei o primeiro não abandonava nunca as naus para não ser detido ou aprisionado, apenas de modo fugaz desembarcou para se apresentar ao Samorim de Calecut. Garcia da Orta, ao contrário, junto com Martim Afonso cruzou mares e terras indianas:

Tinha acompanhado sempre em todas estas empresas o seu padrinho e enquanto este descobria e conquistava terras e avassalava gentes para a coroa de Portugal, Orta ia descobrindo e conquistando conhecimentos sobre os sítios, as raças, os costumes, as línguas, as plantas e as moléstias, amontoando um tesouro preciosíssimo para a ciência, em cuja história marcava lugar proeminente que ninguém poderia disputar-lhe. (CARVALHO, 1934, p. 24)

Como médico pessoal de Martim Afonso, acompanha-o em todas as empresas realizadas no interior do continente indiano. Garcia da Orta cruza a costa de

6 Cabe ressaltar que Garcia da Orta não foi médico só de Martim Afonso, mas também de outros governadores notáveis como D. João de Castro, e Pedro de Mascarenhas. 
Cambaia, visita o Templo de Elefanta, assiste à assinatura do tratado de aliança que Martim Afonso faz com o sultão Badur, no qual é cedida Baçaím. Em 1535 está em Diu, onde os portugueses não tinham ainda construído a célebre fortaleza e atravessa toda a península do Guzarate numa expedição militar comandada por Martim Afonso em apoio ao sultão Badur, dirigida contra os Mongóis. Em 1537 estava em Cochim, onde assiste à tomada de Repelim e à batalha de Beadalá, depois passa algum tempo em Ceilão e Malabar, onde se recolhe a Cochim e mais tarde a Goa.

Nesses episódios, ocorridos entre 1534 e 1538, Garcia da Orta deve ter feito valer o seu saber médico perante os dirigentes locais e os sábios que o rodeava, tendo como declarado propósito:

[...] o grande desejo de saber das drogas medicinais (as que chamavam lá em Portugal de botica) e destoutras mezinhas simples, que qua ha, ou fruitas todas, e da pimenta, das quais cousas queria saber os nomes em todas as línguas, assi das terras donde nascem e das arvores ou prantas que as crião, e assi queria saber como usaõ dellas os físicos indianos, e também queria saber dalgumas outras plantas e fructos desta terra, ou cousas que nella acontecerão, porque todas estas cousas ham de ser ditas na verdade. (ORTA, 1987, p. 19)

Após quase trinta anos de experiência e sabedoria médica acumulada no continente indiano, Garcia da Orta publica os Colóquios dos Simples e Drogas da Índia em 1563, carregando com ela não só os conhecimentos naturais, mas também a marca da diáspora que sofrera e que representa o drama histórico da expulsão dos judeus da Península Ibérica e do consequente monopólio católico do Ocidente. Diante desse conflito cabe perguntarmos: como uma obra de tanta intensidade moral é incorporada pela matéria medica?

A resposta consiste na fundamentação dialógica da matéria médica, o que contribuiu bastante para uma incorporação mais segura e oculta das suas marcas identitárias. Junto às novidades científicas, então, seria conscientemente acrescido ao texto outros aspectos que analisaremos com afinco mais adiante. Nesse ponto, devemos salientar o contexto pré-científico do século XVI, no qual a medicina ainda não era um campo de saber totalmente legitimado, no entanto ela parecia ter o papel de centralizar o conjunto de vários outros conhecimentos. 
Assim como dizia Bakhtin, "a época em que viveu Rabelais foi, na história das ideologias européias, o único período em que a Medicina esteve no centro de todas as ciências, não apenas das ciências naturais, mas também das humanas, [...]" (BAKHTIN, 1987, p. 316). Aliás, a época de Garcia da Orta viveu um renascimento botânico e farmacológico constituído pela síntese tanto da erudição recuperadora dos clássicos, quanto das pesquisas empíricas proporcionadas por uma noção experimental que foi intensificada pelas navegações ultramarinas.

Portugueses e Espanhóis, quando navegavam para as zonas afastadas, se preocuparam em levar e trazer dos continentes que descobriam plantas, animais e minerais como amostras de terras estranhas. Às viagens somava-se, portanto, a prática descritiva que incluía nos tratados novas plantas e novos costumes. O contato intercultural provocado pela expansão européia permitiu, no período moderno, que alguns intelectuais superassem a referência textual clássica renascentista e o empirismo exclusivamente europeu dos primeiros médicos e botânicos dos Quinhentos.

Garcia da Orta é o exemplo de que as navegações constituíram uma fase indispensável para a especialização dos estudos biológicos e médicos com o surgimento posterior da classificação sistemática, da morfologia e da fisiologia vegetal. Apesar da divisão em cinquenta e nove colóquios, cada um destinado a um elemento da botica oriental diferente, sua obra não chega às definições científicas de um herbário moderno ao deixar de avançar por completo nessas especializações. As plantas, assim como alguns animais, foram nessa obra identificados analogamente, quando não inventariados e classificados em função de sua utilidade para a humanidade, sintetizando uma verdadeira descrição de outros costumes, como uma etnografia moral dos usos dos alucinógenos, dos afrodisíacos e de outros remédios.

Contudo, Orta é bastante metódico na sua exposição sobre os fármacos da Índia. Escreve cada capítulo dos Coloquios seguindo o mesmo método. Trata em primeiro lugar dos nomes que definem a identidade da planta a partir dos nomes que lhe são dados em português, grego, latim, sânscrito, árabe e nos vários dialetos locais. Posteriormente, indica a sua procedência geográfica, os países onde aparecia espontaneamente ou era cultivada e, a seguir, os mercados para onde iria convergir. Consequentemente faz a descrição da planta, folhas, caule, flores e frutos. Finalmente, trata, com muito mais dedicação, das aplicações terapêuticas e da administração das mezinhas. 
$\mathrm{Na}$ verdade, na descrição das plantas, encontrava Orta dificuldades, pois a morfologia e a terminologia botânicas estavam muito pouco desenvolvidas. 0 mesmo aconteceu com todos os outros autores da época. Não havia, por exemplo, termos para designar as pétalas e outras partes da flor. Para ultrapassar algumas dificuldades, Orta recorria à analogia das plantas indianas com as existentes em Portugal e Espanha, estabelecendo, assim, "identificações através dos nomes e pela história dos locais de origem de cada planta; dá-nos assim uma ciência em statu nascendi" (LUZES, 2008, p. 99).

Isso nos mostra que, em termos de matéria médica, os Coloquios estão situados entre os antigos phisiologus ${ }^{7}$ e os herbários modernos, ou seja, carrega influências da tradição sem deixar de avançar no conhecimento médico-botânico. Os phisiologus antigos consistiam em "um conjunto multifacetado de informações sobre a natureza, cuja estrutura e conteúdo eram extremamente heterogêneos e diversificados, atingindo mesmo, por vezes, a contradição por suas informações serem basicamente provenientes de vários outros livros antigos" (APARÍCIO; PELÚCIA, 2006, p. 222). Diferente de um phisiologus, os Coloquios de Garcia da Orta despertam o saber herbóreo por direcionar o conhecimento natural no "caminho evolutivo de uma compreensão mais detalhada e sistemática da natureza" (CARNEIRO, 2002, p. 13-14).

Estar diante dessa obra é como estar diante de um "grande bazar indiano" (FICALHO, 1986, p. 97), onde Orta é exposto à venda dos mais variados produtos, misturando-se na pitoresca confusão do mercado de Goa. Longe de precisar consultar os tratados antigos, as especiarias estavam ao seu alcance e eram detalhadamente observadas e experimentadas muitas das vezes. Para descrever as feiras frequentadas, Orta utilizou um pouco de cada uma das línguas que lá encontrara, caracterizando o bazar dos Colóquios em uma espécie de Babel Renascentista, nomeando os produtos no arábico, no persiano, no guzarati, no marathi, no grego, no latim e na língua franca do Mediterrâneo.

\footnotetext{
7 Nome derivado do grego que significa naturalista. "Apesar das dúvidas, a primeira composição de um Phisiologus parece ter tido origem por volta do ano 140 em Alexandria. Ele é identificado como uma obra de cunho enciclopédico elaborada durante a antiguidade, a qual reunia um conjunto de saberes variados extraídos de Horapólon e de Hermes Trimegistos. Esse conjunto de conhecimentos foi herdeiro de trabalhos clássicos de Ctésias, Aristóteles, Plínio, o velho, Élio, Solino, Opiano e de alguns padres da Igreja como São Teófilo, Santo Agostinho e Santo Ambrósio" (APARÍCIO; PELÚCIA, 2006, p. 222-223).
} 
Sendo assim, sua obra muito contribuiu para que, no século XVI, Portugal atingisse o "esplendor no que respeita ao saber pré-científico" (CARVALHO, 1980, p. 41) e, segundo o historiador Joaquim Barradas de Carvalho, D. João de Castro, Pedro Nunes e Garcia da Orta foram os maiores representantes desse esplendor. Cabe ressaltar que é lamentável que os historiadores da filosofia e ciências naturais que pesquisam sobre o século XVI continuem a ignorar valores portugueses, como esses intelectuais. A necessidade de tal reconhecimento demandou longos e intensos debates entre diversos estudiosos de países diferentes, pois cada um sempre justificou a sua respectiva nação a importância sobre a fundação técnico-científica da expansão marítima européia e, de uma forma geral, da moderna cultura ocidental.

Para não criarmos dúvidas sobre o valor científico da obra de Orta basta mencionarmos as sucessivas traduções e reimpressões que seus Coloquios tiveram por meio das quatro edições latinas traduzidas pelo cientista francês Jules Charles l'Ecluse (Clusius, 1526-1609) no período de um século. Esse número de edições de uma mesma obra era realmente fora do padrão para a época.

Tais dados significam que a obra de Garcia da Orta obteve muito mais repercussão como obra científica no estrangeiro. Em Portugal, com o atrasado interesse pela ciência, os Coloquios serão reeditados somente no século XIX, por meio de um trabalho minuciosamente organizado pelo botânico e historiador português Conde de Ficalho ${ }^{8}$ (1837-1903). A rica pesquisa histórica que esse intelectual realizou acerca da obra de Garcia da Orta apresenta, porém, um limite acerca da apreensão do drama específico constituído nesses diálogos.

Sua opinião era de que a escrita dos Coloquios revelava a inexperiência de escrever do seu autor: "Quantas frases mal aprumadas! Quantas repetições inúteis! E, sobretudo, que deplorável falta de método! Pega de uma questão, depois passa a outra, depois volta à primeira numa exposição enredada, que frequentes vezes põe o leitor em torturas" (FICALHO, 1986, p. 282-283). Para quem esperava do texto uma estrutura retórica abreviada, cuja linha principal era simplesmente a organização das informações medicinais, provavelmente não possuía

\footnotetext{
8 Há um verdadeiro projeto por parte do Conde de Ficalho (Francisco Manuel de Melo Breyner) para pesquisar os Colóquios de Garcia da Orta. Seu projeto se inicia com a publicação da Flora dos Lusíadas em 1880, continua com Garcia da Orta e o seu tempo, em 1886, que serviu de preparação aos dois volumes dos Colóquios, editados em 1891 e 1895.
} 
noção de que o rico material que constitui a obra deixa entrever a aproximação de domínios distantes do saber como a arte poética e as ciências médicas.

Apesar do esforço de Orta em se concentrar nas questões provenientes da botânica e da farmácia, ele "não quis fazer apenas um imenso sumário acumulativo de dados sobre a medicina botânica tropical, quis algo mais e o conseguiu, esse algo mais reside na polêmica epistemológica, no abandono duma simples prática informativa do saber" (BARRETO, 1983, p. 258).

\section{Identidade sob raízes, plantas e frutos: Garcia da Orta se descobre na Índia}

Primeiramente, é de suma importância informar que há já consolidada uma linha poética de abordagem desses diálogos ${ }^{9}$. Ela foi explorada inicialmente por Augusto da Silva Carvalho, em trabalho clássico sobre Garcia da Orta, e, mais recentemente, por Márcia Arruda Franco, em artigo publicado pela Revista Camoniana. Com tais estudos, releva-se um "mecanismo de autocensura" (FRANCO, 2002 , p. 120) correspondente à manifestação dialógica dos Coloquios, ou seja, uma operação dramática que contrasta, no texto, os valores da instituição católica com a expressão de seu judaísmo.

De uma forma geral, tais questões político-religiosas regem as críticas realizadas aos Colóquios e seu autor. Conde de Ficalho nada falara, no século XIX, de sua identidade religiosa. É necessário esperar o ano de 1934, para que a suspeita da sua identidade de judeu converso fosse levantada pela investigação promovida por Silva Carvalho.

Entretanto, em 1963, Abílio Martins refuta sua tese ao defender $O$ catolicismo de Garcia de Orta. Segundo esse crítico, "o perfil histórico de Garcia de Orta tem sido objeto de interpretações deformantes e mesmo autenticamente caluniosas, que levam a fazer, do seu caráter, personalidade e convicções íntimas, uma ideia falsa e moralmente bem pouco dignificante" (MARTINS, 1963, p. 35). Acrescenta ainda que é

\footnotetext{
9 "O escritor Almeida Garrett chegou a estar indigitado pela Sociedade de Ciências Médicas de Lisboa para dirigir a primeira reedição dos Colóquios, segundo Conde de Ficalho. Garrett abraçou com entusiasmo a ideia da Sociedade, sem nunca levar por diante a reedição projectada, apesar de pôr bem alto o interesse científico e histórico dos Colóquios, que classificou como «um tratado de ciência que é também um momento da história da arte e da linguagem»" (LUZES, 2008, p. 100).
} 
um anacrônico sectarismo, cientificamente desqualificante, que o leva a querer fazer, à viva força, de Garcia de Orta, um autêntico <<marrano>>, no sentido tradicional de <<cripto-judaizante $>$, incessantemente com medo da inquisição e incapaz de reagir com a naturalidade fácil e despreocupada dum cristão convicto e sincero do seu tempo. (MARTINS, 1963, p. 35-36)

Concordamos com Abílio Martins no que tange à existência de uma tendência fácil e simplista de fazer qualquer figura histórica ser proveniente de sangue hebreu, como se o disfarce das verdadeiras crendices se explicasse apenas pelo terror da inquisição. No entanto, esse não é o caso de Garcia da Orta, cujos aspectos judaizantes são bastante claros na documentação disponível e no próprio texto dos Coloquios.

O que há é certo cristocentrismo político explícito nesse texto, que "a todo o momento disfarça a sua condição judaica com referências bem-comportadas ao padrão da religiosidade cristã. O médico naturalista põe em evidência a sua prática cotidiana de cristão, dizendo que vai a $<<$ Sam Domingos ouvir missa $>>$, [...]" (FRANCO, 2002, p.123). Mas, no Colóquio XXX Do Linaloes, ele é mais direto quanto à sua maior preocupação: "Não queria eu os frades repressores senão no púlpito" (ORTA, 1987, v.2, p. 54).

Além do mais, ele evidencia sua relação forçosa com a instituição católica da época em vários momentos, tratando sua subordinação ideológica de forma irônica e desgastada, como apresenta na frase a seguir: "porque eu nam tenho nenhuma cousa destas por boa, até que digam os que regem a Santa Madre Igreja de Roma" (ORTA, 1987, vol.2, p. 337):

Para Silva Carvalho, o cuidado discursivo em ocultar a sua condição judaica falha algumas vezes, como quando Orta admite a superioridade dos judeus: “[...], os gregos foram os primeiros escritores nas cousas humanas, porque nas divinas primero escreveram os Hebreos". A posição do próprio Orta parece relatada nessa descrição de um sabedor: "E eu quando vim de Portugal, perguntava a um cristam, que havia sido judeu, sendo espanhol, e morava no Cairo". (FRANCO, 2002, p. 124)

Todavia, o disfarce poético de sua identidade surge efetivamente em frases conflituosas como: "porque eu, estando em Espanha, não ousaria dizer cousa alguma contra Galeno e contra os gregos" (ORTA, 1987, vol.2, p. 83-84). Note que, 
nessa frase, temos, a principio, a aceitação dos padrões normais de agregação ao humanismo clássico que predominava no período inicial do Renascimento, mas, em uma segunda leitura evidencia-se uma afirmação que está semi-oculta na frase e que consiste na assimilação de outras culturas e outras autoridades do conhecimento, já que Garcia da Orta não se encontrava em Espanha e podia abandonar ou falar mal da permissiva cultura clássica o quanto desejasse.

Considerando, aliás, que o tribunal da inquisição foi sendo implementado em Goa desde o ano de $1560^{10}$, três anos antes da publicação dos Coloquios, podemos inferir que a presença de seu judaísmo se traduz nas próprias marcas editoriais da sua obra. Para burlar uma censura mais sistemática aplicada ao texto, há diversas indicações de que a edição dos Colóquios foi realizada às pressas. Em primeiro lugar devemos apontar a ausência de figuras ilustrando o aspecto das plantas descritas. Essas ilustrações eram muito utilizadas nos chamados "herbais", tanto que, posteriormente, encontramos essas ilustrações nas edições dos Coloquios de Clusius em 1567 e na edição de Cristóvão da Costa (1515-1594) publicada em 1578.

A renúncia à utilização do latim em favor do português na edição original também pode ser um indicativo dessa precipitação. Dimas Bosque, na nota introdutória dirigida ao leitor, explica que o latim foi abandonado como resultado de um desejo de fazer chegar a obra a um maior número de pessoas de sua estirpe. Porém, o resultado obtido foi o inverso. Os Coloquios, na sua versão portuguesa, tiveram muita pequena difusão e só alcançaram maior prestígio através das mencionadas edições em latim.

Indicativo ainda mais forte e que mais nos satisfaz, é o de que a língua é tratada por Garcia da Orta em seu aspecto sociocultural, tomando a veiculação da ciência na língua nacional uma forma de valorizar a própria pátria enquanto história e enquanto identidade. Com efeito, a língua é entendida pelo médico "não só como um mero instrumento ou suporte para a transmissão de mensagens, conhecimentos, ideias, mas é, acima de tudo, entendida como veiculadora de memória histórica e, em certa medida, da alma da nação" (FRANCO, 2000, p. 234-235).

10 "Em Goa, ergueu-se logo um vistoso edifício do Tribunal e o primeiro grão-inquisidor, arcebispo Gaspar de Leão, a 29 de setembro de 1565, publicou um apelo "ao povo de Israel", [...]" (KAYSERLING, 2009, p. 322). 
Nessa esteira de sensibilidades escriturais, acrescenta-se o fato de que o judaísmo, peculiarmente, não toma a linguagem como expressão da vontade divina. Em seu significado original, ela é, antes de qualquer ato, uma fonte de interpretação, tendo a Torah como a promessa de um sentido múltiplo, um convite à interpretação e reinterpretação contínuas do mundo. Esse parece ser um dos princípios que rege o livro de Garcia da Orta, visto que não só a natureza Oriental está em jogo, mas também a palavra que a veicula, repleta de significados, detalhe que pode ser apreendido pelas várias línguas presentes na denominação e na definição dos fármacos:

Este é o conceito que Gershom Scholem chamou de "propensão preexistente", a idéia de que a Torah implicitamente contém toda interpretação que os comentadores posteriores eventualmente descobririam. [...]. Como expressou o Rabi Joshua ben Levi, um professor Palestino do século três, "Torah, Mishnah, Talmud e Agga-dah deveras, até mesmo os comentários que algum aluno brilhante fará um dia a seu professor - já foram dados a Moisés no Monte Sinai". E, como acrescentou Scholem, "mesmo as questões que tal aluno brilhante fará um dia a seu professor!" (HARLAN, 2014, p. 45-46)

Na reflexão judaica apresentada acima, a natureza deve ser apreendida pelos vários nomes criados por Deus. Segundo Harold Bloom, nessa perspectiva "os tropos ou torções de linguagem - expressam a criação de Deus. [...] Elas não são personificações alegóricas e embora tenham uma potência extraordinária, trata-se mais de um poder de significação do que propriamente daquilo que, em geral, pensamos como magia" (BLOOM, 1991, p. 34-35).

Nesse sentido, os antigos rabinos e cabalistas dessa religião explicavam que a ordem, a harmonia e as influências dos céus sobre o mundo eram totalizadas pelas 22 letras hebraicas dadas a Moisés, alegando, assim, que cada uma delas contém um mistério e um atributo que se refere à divindade ou a algum tipo de inteligência criadora.

Diante de todo esse arsenal de crendices e filosofias que possivelmente habitava o horizonte de Garcia da Orta, não nos parece que a organização dos Colóquios dos Simples em ordem alfabética foi por acaso. Mesmo diante do fato de que os mais antigos livros de índole médico-botânica já tivessem adotado a ordem alfabética e ainda que na sua obra, Orta a não considere como a organi- 
zação mais apropriada: "[...] isso que dizeis da ordem do alphabeto acho nam ser bom, e a causa he, porque pode aconteceras cousas ditas ao princípio serem pouquo proveitosas, ou muito notas, ou sem gosto pera serẽ leidas" (ORTA, 1987, p. 23). Quem sabe essa negativa não seja mais uma de suas dissimulações dialógicas?

Sobre esse aspecto, observamos também que os diálogos permitem-nos acessar um saber que se constrói e que não será definitivo como supunham os tratados médicos oferecidos pelos antigos. Nessa perspectiva, há passagens verdadeiramente cênicas nas quais se registra as mais diversas figuras e os mais curiosos casos em que Ruano é uma espécie de alter ego do autor, além de ser seu principal interlocutor, representante acadêmico das universidades ibéricas onde estudara. Ruano é apresentado inicialmente no convés de uma nau que acaba de chegar a Goa, e por meio desse latino recém-chegado vemos quais eram as disposições de Garcia da Orta trinta anos antes da publicação dos Coloquios, ao chegar pela primeira vez à Índia.

No entanto, esses aspectos revelam-se apenas como parte de sua disposição poética. O seu grau dialógico é intensificado quando observamos como o texto se porta em relação especialmente às questões político-religiosas de seu tempo. Observamos com isso que Garcia da Orta não só critica o conhecimento médico de então com tais polêmicos diálogos, expondo o contraste entre sua experiência diante do saber livresco de Ruano.

Longe de limitar-se ao registro dos fármacos e das façanhas dessas viagens, nos Coloquios, a viagem e o conhecimento adquirido por Garcia da Orta carregam outro sentido, tornam-se uma diáspora, visto o alavancar dos conflitos e discriminações sociais de que os judeus eram vítimas por toda Europa. Em nossa hipótese de leitura, no intuito de obter um legítimo registro memorial de sua tradição e de sua condição humana através dos fármacos, Orta configura tais diálogos delineando seu interesse pelos simples e drogas de acordo com os costumes dietéticos da religião judaica. Obviamente que esses elementos sagrados da natureza se apresentarão no texto sem explicitar sua importância religiosa e ritualística, apenas a sua função medicinal.

Para realizarmos esse reconhecimento, é necessário ter em conta que falar da natureza é também um ato religioso, um rito que envolve o alimento que o judeu consumiu ao longo de séculos, sofrendo restrições pelas condições de desterro em que sempre vivia. Isso constituiu sua tradição tanto medicinal 
quanto culinária. Muitos frutos e plantas são considerados sagrados para essa religião, principalmente os elementos que acreditam fertilizar vigorosamente a Terra Prometida. Por isso, cabe nos atentarmos brevemente para alguns desses elementos da natureza presentes nos Coloquios dos Simples e Drogas da Índia, obra que, a partir de agora, tomaremos como a alegoria de um jardim sagrado.

Segundo a Torá, especificamente o livro Deuteronômios, 8, desses produtos releva-se, entre outros, a oliva, a tâmara, as amêndoas, as nozes, a canela e o vinho. A oliva, por exemplo, é muito mencionada, principalmente no Coloquio Sexto Do Arvore Triste, em que ela é comparada à árvore da vida do hinduísmo: "Ruano: [...], não tomeis trabalho em dizer a grandura e feiçam do arvore, pois vejo ser do tamanho de huma oliveira, [...]" (ORTA, 1987, p. 71).

Teria Orta realizado conscientemente uma analogia da ritualística planta indiana com a simbologia sagrada das oliveiras na cultura judaica? Os hindus julgam esta arvore procedente do céu, de onde Krishna trouxe a sua mulher Satayabhãma por causa do fino perfume das suas flores e, por isso, essas flores são usadas no culto prestado a todos os deuses hindus: “Orta: [...] este arvore muyto bem cheira em tanta maneira que leixa de comer o que tem pera o gastar em cheiros, [...] em Ormuz os trabalhadores, que ganhão de comer a carretar fato, compram os cheiros para se untar de noite, e deixão de comer" (ORTA, 1987, p. 71).

Esses interesses não surgem por acaso ao longo das conversas e sim com segundas intenções, o que é confirmado quando se ressalta no texto, por exemplo, os elementos fundamentais para a comemoração da Pêssach (páscoa judaica). Nessa comemoração, é tradição a presença de uma mesa de alimentos em que há uma reconstituição simbólica da historia da saída dos judeus do Egito. À mesa, portanto, são dispostos alimentos simbólicos, a fim de trazer à memória essa experiência. Dos alimentos, mencionamos o Charósset, uma mistura de nozes, tâmaras, canela e vinho, que representa a argamassa com a qual os judeus trabalhavam na construção das edificações do faraó.

Com exceção do vinho ou da uva, há colóquios dedicados exclusivamente a todos esses alimentos sagrados. No Coloquio Decimo Quinto Da Canela, Orta, através da fala de Ruano, não hesita em afirmar que "Nenhuma especeria se póde comer com gosto, senam canela: [...]" (ORTA, 1987, p. 201), além de ser uma "gentil mezinha pera o estomaguo, e pera tirar a dor da coliqua, [...]" (ORTA, 1987, p. 213). 
Quanto ao tamarindo, tratado exclusivamente no Coloquio Quinquagesimo Terceiro, ele se encontra em tão grande quantidade na casa de Garcia da Orta que Ruano pede a ele uma porção para levar na viagem de retorno à Espanha: "Orta: Eis aqui o tamarindo. Ruano: He muyto gentil conserva, e sabe muyto bem. Faça me mercê de alguma pera a levar, que quero antes que açucare rosado de Alexandria" (ORTA, 1987, v.2, p. 320-321).

No Coloquio Trigesimo Segundo Da Maça e Noz, por sua vez, nos deparamos com uma imagem muito curiosa da noz:

E aveis de saber que, quando esta noz he madura, vais inchando, e rompe a primeira casca como fazem os ouriços das castanhas nossas, e fica a maça muyto vermelha, parecendo como gram fina; que he a mais fermosa cousa de ver no mundo, quando as arvores estam carregadas; e ás vezes tambem a maça se fende, e esta he a causa onde a noz muytas vezes não vem çercada da maça. (ORTA, 1987, v.2, p. 82)

Não nos transmite essa imagem descrita do amadurecimento da noz rompendo a sua casca uma esplendorosa metalinguagem, visto que é possível tomarmos analogamente a noz como sua identidade oprimida e a casca como o cristianismo político em meio à permissiva matéria médica? A identidade de Garcia da Orta ressurge como uma noz, sendo os Colóquios a sua casca a ser rompida dialogicamente.

Parece-nos, aliás, que a todo o momento Garcia da Orta está testando a proximidade do continente indiano e sua botica com aquilo que os judeus tomavam por sagrado e por paraíso terral. Exemplo disso são também os vários outros momentos em que o diálogo é deslocado do núcleo medicinal, dado mais abertura ainda às analogias: "Ruano: E agora me dizei o que sabeis da ilha de Ceilam, pois he tão celebrada. Orta: [...]; e entre os negros qua dizem os Indios ser o paraizo terreal; e ha huma serra, que ahi há muyto alta, que chamam o pico de Adam, e dizem que está ally a pegada de Adam, [...]" (ORTA, 1987, p. 217).

Além da imaginária ilha de Taprobana localizada por Camões no Ceilão, devemos nos atentar para os aspectos judaicos presentes na parte em que Garcia da Orta se refere à guerra da Ilha de Repelim, no mencionado colóquio da canela: 
Os Chins navegarão esta terra muito tempo ha; e como a gente d'ella era Barbara e sem nenhum saber, tomavam delles as leis e costumes, [...]. E em Calecut tinhão uma feitoria, como fortaleza, que oje em dia permanece, e se chama China cota, que quer dizer fortaleza dos Chins. E em Cochim leixarão huma pedra por marquo, e em memoria que ali chegarão os Chins; e quando elrey de Calecut cercou a Cochim, [...], destruyo Cochim, e levou dally aquela pedra, em logar de trofeo, o qual Ihe tem custado bem caro. E nesta pedra se coroava em Repelim, tomando a coroa por elrey de Repelim, que na cabeça Iha punha, e Ihe fazia homenagem; e em este Repelim ficou aquella pedra por mandado do Çamorim. Este Repelim está apartado quatro legoas de Cochim, onde ficou a pedra até ao anno de 1536, que Martim Afonso de Sousa, nam menos envencivel que afortunado capitam, sendo Capitão mor do mar, destruyo Repelim e queymouo e saqueou, fugindo elrey com muita gente; [...]. (ORTA, 1987, p. 205)

Nessa descrição, não estaria nosso médico centrado por demais na mística pedra branca, que fora o motivo da desavença entre os reis indianos? Não estaria Orta desconfiando ter essa pedra semelhante poder como àquela sonhada por Jacob, que constituía simbolicamente uma escada ligando a terra e o céu por onde subiam e desciam os Anjos proféticos? Ou mesmo um poder místico análogo à pedra fundamental sobre a qual se fundou o Templo de Jerusalém, ou ainda comparável "à pedra profetizada por Daniel, a partir do sonho do rei Nabucodonosor, a qual, caída de um monte, derrubaria uma estátua figurando vários reinos, prenunciando assim o advento da derradeira monarquia ou governo messiânico" (FRADE; SILVA, 2011, p. 86-87)?

Resumindo, tais interesses peculiares que se distam da matéria médica, como nos casos da ilha de Ceilão e da pedra mística da ilha de Repelim, só nos revelam que Garcia da Orta, apesar de pregar uma verdade empírica contra os antigos, não se afasta "de uma força imaginária através da qual os cristãos-novos buscavam refúgio, baseando-se nas ideias místicas de redenção messiânica e de martírio" (NOVINSKY, 1986, p. 24).

O mais interessante nisso tudo, todavia, é que tais apropriações não impediram que Orta aceitasse a superioridade dos orientais na valiosa prática medicinal. Essa abertura pode ser percebida pelas muitas conversas que o médico diz ter travado com os baneanes, que eram os mercadores indianos: "[...] estando uma tarde no bazar passou por essa porta huma mulher com hum saco de turbit 
já seco e lho vendia; e eu como conhecia a mezinha, e avia ouvido dizer que dali o levavam para as nossas nãos, perguntei ao Baneane que era aquilo" (ORTA, 1987, p. 329).

Quando todos os europeus desprezavam o convívio com os hindus e muçulmanos, Orta, despido parcialmente de vaidades e preconceitos, vagueava humildemente anotando tudo que merecia registro e "conversando com a gente do povo indiano, sem se ater a sua baixa condição, não se envergonhava de tratar um baneane por seu amigo (Colóquio XII, p. 155), e de uns e de outros coligia as informações preciosas que o haviam de guiar nas pesquisas e notas" (CARVALHO, 1934, p. 26).

Porém, é explícito o extremo cuidado com que evita falar dos hindus, dos hebreus ou dos árabes e, quando a eles se refere, utiliza sempre a terceira pessoa para cuidadosamente deles se distanciar: "Ruano: Quem vos dixe isto, e como o sabeis? Orta: Hum judeu que foy a Portugal, nacido no Cairo, que levou a Portugal as novas do Soldam Bhadur, e chamado por nome Isaque do Cairo, homem discreto e sabedor de muytas lingoas, [...]" (ORTA, 1987, v.2, p. 85).

Quanto ao judeu citado em terceira pessoa, no processo inquisitorial de Catarina da Orta consta a afirmação de que Isaque do Cairo é primo de sua irmã, consequentemente ele também é parente de Garcia da Orta, o que não corrobora o distanciamento ou quase estranhamento com que ele foi apresentado nesse trecho do colóquio da noz ${ }^{11}$. Com essa afirmação, podemos nos sensibilizar mais para o extremo cuidado de Orta ao se afastar de qualquer reconhecimento familiar ou qualquer suspeita de heresia, não deixando, contudo, de mapear o texto com seu ciclo de contatos, tradições e amizades.

\footnotetext{
11 "Catarina d'Orta denunciou seu primo Jorge Pinto, que andava na Índia com o nome de Isac, e na família era conhecido por Isaquito" (CARVALHO, 1934, p. 74). "Assim a 13 de Julho veio depor que o homem chamado Isaac, que era Jorge Pinto, de Castelo de Vide, e andava com nome e hábito de judeu, se chamava Isaquito, era filho de Bartolomeu Pais, morador em Castelo de Vide e se fôra com Clara Dias, irmã de Leonel Gonçalves, seu marido" (CARVALHO, 1934, p. 162).
} 


\section{Considerações Finais}

Esse paradoxo no texto remete à dialogicidade interna que penetra em toda sua estrutura, em todos os seus estratos semânticos e expressivos, aspectos esses que foram quase que absolutamente ignorados pela maioria das críticas realizadas a respeito de sua obra. Sua estrutura não tanto desenvolvida e clara provavelmente dificulta essa apreensão, mas podemos arriscar a dizer que nos Coloquios de Garcia da Orta encontramos um embrião dialógico do que posteriormente se estabelecerá com a prosa romanesca.

Para reforçar essa hipótese, cito novamente Bakhtin que ressalta que "o desenvolvimento do romance consiste em um aprofundamento do diálogo, do seu alargamento e refinamento [...]" (BAKHTIN, 1993, p. 105-106). A busca de uma leitura atenta à estrutura dialógica dos Coloquios levou-nos a estudar a unidade discursiva na sua configuração interna metafórica e paradoxal, acolhendo o discurso de Garcia da Orta no seu ponto fulcral de construção.

Ademais, esse emprego dialógico do texto de Orta tem em seu núcleo constituinte o que é provavelmente a característica mais original do posterior romance burguês: o retrato de todo tipo de experiência humana e não só as que se prestavam às perspectivas institucionais: "seu realismo não está na espécie de vida apresentada, e sim na maneira como se apresenta" (WATT, 1990, p. 13). Desse modo, nos parece coerente tomar os Coloquios como o prenuncio de uma tendência estética favorável à particularidade, que logo começou a se firmar, em grande parte, graças à literatura e filosofia modernas, da qual evidentemente não trataremos aqui.

Longe de representar uma busca cega pelas verdades no conhecimento medicinal, os Coloquios mostram, acima de tudo, alguém que não podia viver de acordo com a sua realidade (de judeu), por isso tinha de tentar assimilar algo dela no campo científico. Foi assim que Garcia da Orta procurou na Índia e na ciência um refúgio e uma fortaleza comum que seria uma espécie de mundo novo, diferente da realidade aparente e opressiva que tinha conhecido e vivido na Península Ibérica:

Como indício desta liberdade íntima que procurava é de sublinhar que Orta, além da história das drogas e especiarias, nos vai contando a sua própria vida, só não incluindo o relato do inferno que a sua condição de cristão-novo lhe fez atravessar. 
A escrita dos Colóquios não transformou só o saber sobre as coisas da Índia, mas fez nascer em Garcia outro homem que depois o transporta. Já não temos perante nós o homem que quer negociar, enriquecer, conquistar todo o saber sobre a Índia. No final já não quer possuir a Índia, a Índia é que tomou posse dele. (LUZES, 2008, p. 102)

A Índia fez brotar mais um fruto em seu místico jardim e esse fruto chama-se Garcia da Orta, médico em busca de novos conhecimentos e exímio caçador da Terra Prometida, além de plantador de Ortas experimentais. Seus ossos podem ter sido queimados desrespeitosamente pela inquisição, porém sua raiz nunca será retirada do fértil campo da literatura.

Sua tensão ecoa nos subterfúgios não só dos seus diálogos, mas nas descrições de sabores, cheiros e efeitos psíquicos compartilhados com seus leitores. Assim, em sua obra, os sujeitos surgem diversificados como heteronímias que se divergem a partir das variadas percepções e dos variados usos medicinais da botânica e ritos de cura. Nesse trânsito entre novas e velhas infusões, no entanto, Garcia da Orta nos mostra que sua identidade é a mais valiosa mistura, em que a ciência e o sagrado se juntam para divulgar um novo conhecimento proliferado pela ainda desconhecida natureza.

Por fim, gostaríamos de sugerir que esse tema investigativo pode ainda resultar num profícuo paralelo que daria, com certeza, uma pesquisa à parte: o paralelo de que os diálogos de Garcia da Orta se aproximam, em muitos aspectos, das imagens criadas pelo pintor italiano renascentista Giuseppe Arcimboldo (1527?-1593?), porque, além de ambas serem confeccionadas superficialmente por elementos variados da natureza, constituem uma forma humanizada em seu conjunto.

Isso nos incita a afirmar que, longe de ser um simples acúmulo de raízes, plantas e frutos, os Colóquios devem ser compreendidos em sua disposição textual para a figuração humana de seu autor, especialmente sua condição de desterro. 


\section{Referências}

APARÍCIO, João Paulo; PELÚCIA, Paula. O animal e a Literatura de Viagens. Bestiários. In: CRISTÓVÃO, Fernando (coord.). Condicionantes Culturais da Literatura de Viagens. Coimbra: Almedina Centro de Literaturas de Expressão Portuguesa da Universidade de Lisboa, 2002.

BAKHTIN, Mikhail. Questões de Literatura e de Estética (A Teoria do Romance). 3ạ edição. Equipe de tradução de Aurora Fornoni Bernadini. São Paulo: Editora Unesp, 1993.

. A Cultura Popular na Idade Média e no Renascimento - O Contexto de François Rabelais. Tradução de Yara Frateschi. São Paulo: Hucitec, 1987.

BARRETO, Luís Filipe. Descobrimentos e Renascimento: formas de ser e pensar nos séculos XV e XVI. Lisboa: INCM, 1983.

BLOOM, Harold. Cabala e Crítica. Tradução de Monique Balbuena. Rio de Janeiro: Imago Ed., 1991.

CARNEIRO, Henrique. Amores e sonhos da flora: afrodisíacos e alucinógenos na botânica e na farmácia. São Paulo: Xamã, 2002.

CARVALHO, Joaquim Barradas de. O Renascimento Português: em busca de sua especificidade. Lisboa: INCM, 1980.

CORTESÃO, Jaime. A política de sigilo nos descobrimentos. Nos tempos do Infante $D$. Henrique e de D. João II. Lisboa: Comemoração Executiva das Comemorações do Quinto Centenário da Morte do Infante D. Henrique, 1960.

FICALHO, Conde de. Garcia da Orta e seu tempo. Introdução de Nuno de Sampaio. Lisboa: Temas Portugueses, 1986.

FRADE, Florbela Veiga; SILVA, Sandra Neves. Medicina e política em dois físicos judeus portugueses de Hamburgo. In: Revista Sefarad. Madrid/Barcelona, v. 71, n.1, 2011, p. 51-94.

FRANCO, Márcia Arruda. Botânica e Poesia: Camões e Garcia D'Orta em Goa. In: Revista Camoniana. São Paulo: Núcleo de Estudos Luso-Brasileiros; EDUSC, 2002, v.12, p.111134.

HARLAN, David. A história intelectual e o retorno da literatura. In: RAGO, M. (org.). Narrar o passado, repensar a história. Campinas-SP: Ed. Unicamp, 2014, p. 13-60.

KAYSERLING, Meyer. História dos Judeus em Portugal. Tradução de Gabriele Borchardt e Anita Waingort Novinsky. São Paulo: Perspectiva, 2009.

LIPINER, Elias. Gaspar da Gama: um converso na frota de Cabral. Rio de Janeiro: Nova Fronteira, 1987.

LUZES, Pedro. O fascínio do Oriente na vida e na obra de Garcia d'Orta. In: Afreudite, Ano IV, n. 7/8, 2008, p. 85-104. 
MARTINS, Abílio. O catolicismo de Garcia da Orta. In: Revista Brotéria. Lisboa, v. 77, 1963, p. 35-46.

NOVINSKY, Anita W. A Inquisição. São Paulo: Brasiliense, 1986.

ORTA, Garcia de. Colóquios dos Simples, Drogas e Cousas Medicinais da India. Lisboa: INCM, 1987, 2 vols.

WATT, Ian. A ascensão do romance: estudos sobre Defoe, Richardson e Fielding. Tradução de Hildegard Feist. São Paulo: Companhia das Letras, 1990.

WILKE, Carsten L. História dos Judeus Portugueses. Tradução de Jorge Fernandes Campos da Costa. Lisboa: Edições 70, 2009.

Submetido em: 01-12-2015 Aprovado para publicação: 04-08-2016 